\title{
STUDI KONDISI LIMNOLOGIS WADUK SERMO PADA TAHAP PRA-INUNDASI
}

\section{STUDY ON LIMNOLOGIC CONDITIONS OF SERMO RESERVOIR PRE-INUNDATION}

\author{
Bambang Triyatmo*)
}

\begin{abstract}
A study on the limnologic conditions of Sermo reservoir was conducted from September 1996 to January 1997 . Water samples were collected from six stations every \pm 25 days. The samples from each station were collected from 2 to 3 different depths of water. The objectives of this research were to know the physically, chemically and biologically water quality of Sermo reservoir.
\end{abstract}

Results indicated that the water quality of Sermo reservoir was suitable for fishes. The concentration of $\mathrm{NH}_{4}{ }^{+}, \mathrm{NO}_{3}{ }^{-}, \mathrm{PO}_{4}{ }^{3-}$, dan $\mathrm{SO}_{4}{ }^{-}$indicated that the water fertility could support the growth of plankton as natural food for fishes and other aquatic organisms. However, the water quality and its productivity have not been stabile yet. Phytoplankton was more dominance than zooplankton. Number of phytoplankton species were between $10-15$ species, that was dominated by Nitzschia sp., Nostoc sp. and Peridinium. Zooplankton species observed were Brachionus sp. and Cyclops sp. Any aquatic plants were not found.

Key words : Limnologic, pre-inundation, sermo reservoir

\section{Pengantar}

Waduk Sermo merupakan satu-satunya waduk dan yang pertama kali dibangun di Daerah Istimewa Yogyakarta (DIY). Waduk Sermo mempunyai luas sekitar 157 hektar, dengan kapasitas genangan air sebanyak 25 juta $\mathrm{m}^{3}$. Fungsi Waduk Sermo yang dipandang penting dan bermanfaat adalah untuk suplai air irigasi, air bersih / minum, pembangkit listrik mikrohidro dan perikanan. Pengembangan perikanan di perairan Waduk Sermo sangat penting, karena dapat meningkatkan manfaat dan produktivitas waduk, serta memperluas lapangan kerja bagi masyarakat di sekitar waduk. Peningkatan produksi ikan akan menambah penyediaan protein hewani yang berfungsi untuk pemenuhan gizi masyarakat. Tingkat konsumsi ikan di Daerah Istimewa Yogyakarta dipandang masih rendah, baru mencapai sebesar 6,64 $\mathrm{kg} / \mathrm{kapita} / \mathrm{tahun}$, jauh lebih rendah dibandingkan secara nasional sebesar $16,7 \mathrm{~kg} / \mathrm{kapita} / \mathrm{tahun}$. Ikan konsumsi di Yogyakarta sebagian besar dipasok dari luar daerah (Dinas Perikanan, 1995). Upaya pengembangan perikanan di
Waduk Sermo harus didukung dengan studi/penelitian mengenai keadaan dan potensi perairan. Informasi ini sangat penting dalam menentukan kebijaksanaan pengelolaan waduk untuk perikanan.

Pada tahap awal setelah pengisian air waduk akan terjadi perubahan dari ekosistem perairan mengalir (sungai) menjadi ekosistem perairan tergenang (waduk). Pada awal penggenangan akan terjadi perubahan kualitas dan kesuburan air. Produksi hayati di daerah tersebut akan melimpah karena adanya perkembangan biologis akibat dari pelepasan unsur-unsur hara tanah dan bahan organik yang terendam air. Ekosistem waduk pada awal penggenangan mempunyai produksi hayati yang sangat berfluktuasi. Keadaan ini akan berlangsung relatif lama. Perairan waduk mencapai keadaan stabil dalam waktu 2-3 tahun setelah penggenangan. Perubahan dan perkembangan ekosistem yang terjadi perlu dipelajari sebagai dasar untuk menentukan pola pengembangan perikanan di perairan waduk (Kartamihardja dkk., 1991). 
Studi telah dilakukan terhadap keadaan keadaan limnologi perairan Waduk Sermo yang meliputi keadaan kualitas dan kesuburan air, serta kualitas biologi (plankton dan tanaman air). Keadaan tersebut mencerminkan kesesuaian lingkungan hidup dari organisme air tertentu. Tingkat kualitas dan kesuburan air, serta kualitas biologi dapat diketahui dan digunakan sebagai dasar dalam pengembangan perikanan yang produktif.

\section{Bahan dan Metode}

Studi perairan Waduk Sermo mengenai kualitas dan kesuburan air, serta kesesuaiannya untuk perikanan. Pengamatan kualitas dan kesuburan air waduk dilakukan terhadap sampel pada lokasi 6 stasiun, yaitu : S1 : Stasiun 1, daerah aliran masuk sisi utara; S2 : Stasiun 2, daerah aliran masuk sisi selatan; S3: Stasiun 3, daerah tengah waduk; S4: Stasiun 4, daerah tepi waduk sisi utara; S5 : Stasiun 5, daerah tepi waduk sisi selatan; S6 : Stasiun 6, daerah aliran keluar/dekat dam.

Pengambilan dan pengamatan sampel air pada lokasi masing-masing stasiun dilakukan pada permukaan (p) dan dasar (d) perairan. Pada stasiun S3 dan S6 juga diambil dan diamati sampel air pada bagian tengah $(t)$ perairan. Pengambilan dan pengamatan sampel air dilakukan selama 6 periode (setiap \pm 25 hari) yang tersebar pada musim kemarau dan musim hujan (bulan September 1996 sampai dengan Januari 1997).

Parameter kualitas dan kesuburan air yang diamati meliputi kecerahan, kekeruhan (turbiditas), suhu, derajad keasaman $(\mathrm{pH})$, oksigen $\left(\mathrm{O}_{2}\right)$ terlarut, karbon dioksida $\left(\mathrm{CO}_{2}\right)$ bebas, alkalinitas, kesadahan, daya hantar listrik (DHL), padatan terlarut total (total dissolved solid/TDS), amonia $\left(\mathrm{NH}_{3}\right)$, amonium $\left(\mathrm{NH}_{4}\right)$, nitrat $\left(\mathrm{NO}_{3}{ }^{-}\right)$, nitrogen $(\mathrm{N})$ total, fosfat $\left(\mathrm{PO}_{4}{ }^{3-}\right)$, sulfat $\left(\mathrm{SO}_{4}{ }^{-}\right)$dan bahan organik total. Parameter kualitas biologi meliputi jenis dan jumlah plankton dan tanaman air. Produktivitas primer perairan waduk juga diamati.

Metode yang digunakan dalam pengamatan kecerahan dengan "secchi disk" dan kekeruhan dengan turbidimeter, suhu dengan termometer, $\mathrm{pH}$ dengan $\mathrm{pH}$ meter, DHL dengan conductivitymeter, TDS dengan penguapan menggunakan 'oven' pemanas. Pengamatan oksigen $\left(\mathrm{O}_{2}\right)$ terlarut, karbon dioksida $\left(\mathrm{CO}_{2}\right)$, alkalinitas, kesadahan dan bahan organik dengan cara titrasi. Pengamatan amonia $\left(\mathrm{NH}_{3}\right)$, amonium $\left(\mathrm{NH}_{4}\right)$, nitrat $\left(\mathrm{NO}_{3}{ }^{-}\right)$, fosfat $\left(\mathrm{PO}_{4}{ }^{3-}\right)$ dan sulfat $\left(\mathrm{SO}_{4}{ }^{{ }^{\prime}}\right)$ dengan spektrofotometer. Plankton diamati dengan mikroskup dan tanaman air diamati langsung di lapangan. Pendugaan produktivitas primer menggunakan metode botol gelap-terang yang dianalisa dengan modifikasi metode Winkler (cara titrasi) (EPA, 1983; APHA, 1985).

\section{Hasil dan Pembahasan}

Pengamatan kualitas dan kesuburan air waduk Sermo telah dilakukan sebanyak 6 periode, pada bulan September 1996 sampai dengan Januari 1997. Kualitas dan kesuburan air waduk Sermo masingmasing stasiun dapat dilihat pada tabel 1 . Pada Tabel 2 menunjukkan jumlah spesies, kerapatan dan indeks keanekaragaman plankton masing-masing stasiun. 
Tabel 1. Kualitas dan kesuburan air waduk sermo

\begin{tabular}{|c|c|c|c|c|c|c|c|c|c|c|c|c|c|c|c|c|c|c|c|}
\hline Stasiun & $\begin{array}{c}\text { Keda- } \\
\text { laman } \\
(\mathrm{cm})\end{array}$ & $\begin{array}{c}\text { Kece- } \\
\text { rahan } \\
(\mathrm{cm})\end{array}$ & $\begin{array}{r}\text { Turbi- } \\
\text { ditas } \\
\text { (JTU) }\end{array}$ & \begin{tabular}{|c} 
Suhu \\
Udara \\
$\left({ }^{\circ} \mathrm{C}\right)$
\end{tabular} & $\begin{array}{c}\text { Suhu } \\
\text { Air } \\
\left({ }^{\circ} \mathrm{C}\right)\end{array}$ & $\mathrm{pH}$ & $\begin{array}{c}\mathrm{O}_{2} \\
\text { terlarut } \\
\text { (ppm) }\end{array}$ & $\begin{array}{c}\mathrm{CO}_{2} \\
\text { bebas } \\
(\mathrm{ppm})\end{array}$ & $\begin{array}{c}\text { Alkali- } \\
\text { nitas } \\
\text { (ppm) } \\
\mathrm{CaCO}_{3}\end{array}$ & 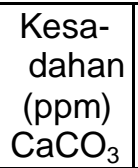 & $\begin{array}{c}\mathrm{DHL} \\
\mu \mathrm{mhos} / \\
\mathrm{cm}\end{array}$ & $\begin{array}{l}\text { TDS } \\
(\mathrm{gr} / \mathrm{l})\end{array}$ & $\begin{array}{c}\text { Amonia } \\
(\mathrm{ppm}) \\
\mathrm{NH}_{3}\end{array}$ & $\begin{array}{c}\text { Amonium } \\
(\mathrm{ppm}) \\
\mathrm{NH}_{4}\end{array}$ & $\begin{array}{c}\text { Nitrat } \\
(\mathrm{ppm}) \\
\mathrm{NO}_{3}\end{array}$ & $\begin{array}{c}\text { Nitro- } \\
\text { gen } \\
\text { total } \\
(\mathrm{ppm})\end{array}$ & $\begin{array}{c}\text { Fosfat } \\
\text { (ppm) } \\
\mathrm{PO}_{4}\end{array}$ & $\begin{array}{c}\text { Sulfat } \\
\text { (ppm) } \\
\mathrm{SO}_{4}\end{array}$ & $\begin{array}{c}\text { Bahan } \\
\text { organik } \\
\text { (ppm) }\end{array}$ \\
\hline Kisaran & $0-32$ & $25-130$ & $\begin{array}{r}<25- \\
131\end{array}$ & $\begin{array}{r}25,0- \\
32,0 \\
\end{array}$ & $\begin{array}{r}26,1- \\
33,0\end{array}$ & $7,0-8,9$ & $\begin{array}{l}1,00- \\
11,20\end{array}$ & $\begin{array}{r}0,00- \\
1,40\end{array}$ & $\begin{array}{l}30- \\
156\end{array}$ & $36-118$ & $67-252$ & $0-32$ & \begin{tabular}{|r|}
$0,003-$ \\
0,245
\end{tabular} & $\begin{array}{r}0,340- \\
1,358\end{array}$ & $\begin{array}{r}0,281- \\
7,062 \\
\end{array}$ & $\begin{array}{r}0,300- \\
11,50\end{array}$ & $\begin{array}{l}\text { Ttd- } \\
1,050\end{array}$ & $8,4-84,9$ & $5,7-22,1$ \\
\hline Rerata & 6 & 67 & & 29,0 & 28,9 & 7,7 & 5,69 & 0,52 & 94 & 73 & 158 & 6 & 0,039 & 0,513 & 1,512 & 1,54 & 0,123 & 33,7 & 12,8 \\
\hline S-p & 0 & 67 & & 28,7 & 30,4 & 8,2 & 8,17 & 0,18 & 97 & 74 & 160 & 0 & 0,073 & 0,469 & 1,232 & 1,41 & 0,118 & 34,2 & 14,6 \\
\hline S-t & 9 & & & & 27,6 & 7,3 & 3,75 & 0,80 & 98 & 80 & 162 & 9 & 0,016 & 0,539 & 1,885 & 1,68 & 0,151 & 32,6 & 11,0 \\
\hline S-d & 12 & & & & 27,7 & 7,4 & 3,87 & 0,76 & 90 & 70 & 156 & 12 & 0,013 & 0,547 & 1,667 & 1,62 & 0,119 & 33,6 & 11,5 \\
\hline
\end{tabular}

Keterangan : $\mathrm{s}$ = stasiun; $\mathrm{p}=$ permukaan; $\mathrm{t}=$ tengah; $\mathrm{d}$ = dasar; TDS; Total Dissolved Solid; DHL = Daya Hantar Listrik 


\section{Kecerahan dan kekeruhan air}

Kecerahan dan kekeruhan (turbiditas) air menggambarkan tingkat kejernihan air untuk dapat menerima cahaya dari sinar matahari. Hasil pengamatan kecerahan dan kekeruhan air waduk Sermo sekitar $25-130 \mathrm{~cm}$ (rata-rata $67 \mathrm{~cm}$ ) dan kekeruhan (turbiditas) $<25-131$ JTU. Kecerahan dan kekeruhan air dapat disebabkan oleh suspensi tanah (lempung) atau plankton. Kekeruhan di perairan umumnya jarang melebihi 20.000 $\mathrm{mg} / \mathrm{l}$ dan bahkan pada perairan berlumpur biasanya kurang dari $2.000 \mathrm{mg} / \mathrm{l}$. Perubahan perilaku berbagai macam jenis ikan baru terjadi pada kekeruhan lebih besar dari 20.000 mg/l (Irwin, 1945 cit. Boyd, 1979). Kecerahan dan kekeruhan air waduk Sermo termasuk jernih sesuai untuk kehidupan pakan alami (fitoplankton) dan ikan. Pengamatan kualitas air tersebut dilakukan pada bulan yang sebagian besar termasuk musim hujan. Air tersebut diperkirakan akan lebih jernih pada musim kemarau.

\section{Suhu air}

Suhu air dapat mempengaruhi sifat fisika, kimia maupun biologi perairan. Secara biologi suhu air dapat mempengaruhi kehidupan plankton dan fisiologis ikan. Menurut Pescod (1973) cit. Krismono dkk., (1987) perubahan suhu yang disebabkan oleh penambahan air untuk perairan mengalir sebaiknya tidak lebih dari $2,8^{\circ} \mathrm{C}$ dan untuk perairan yang tergenang tidak lebih dari $1,7^{\circ} \mathrm{C}$. Suhu air waduk Sermo berkisar antara $26,1-33,0^{\circ} \mathrm{C}$ (rata-rata $28,9^{\circ} \mathrm{C}$ ). Fluktuasi suhu sebaiknya tidak lebih dari $4^{\circ} \mathrm{C}$, karena pada fluktuasi suhu sebesar $5^{\circ} \mathrm{C}$ atau lebih dapat mengakibatkan ikan stres (Boyd dan Lichkopler, 1979). Suhu air menunjukkan penurunan dengan semakin bertambahnya kedalaman. Beda suhu rata-rata antara permukaan dan dasar perairan sekitar $3^{\circ} \mathrm{C}$. Penurunan ini tidak begitu tajam, sehingga tidak menyebabkan adanya stratifikasi. Suhu air waduk Sermo dan perubahannya secara mendadak tidak terjadi, sehingga mendukung untuk kehidupan pakan alami dan ikan

\section{Derajad keasaman $(\mathrm{pH})$}

Derajad keasaman $(\mathrm{pH})$ air dapat mempengaruhi kesetimbangan senyawasenyawa yang terdapat di dalam perairan, disamping itu mempengaruhi kehidupan pakan alami (plankton) dan fisiologis ikan. Menurut Swingle (1969) cit. Boyd (1979) dalam suatu perairan dengan $\mathrm{pH}<5$ ikan tidak berkembang atau mati, $\mathrm{pH}<6,5$ pertumbuhan ikan lambat, $\mathrm{pH}$ 6,5 - 9 layak untuk kehidupan ikan, $\mathrm{pH}>9$ pertumbuhan ikan lambat dan pada $\mathrm{pH}>11$ menyebabkan kematian ikan. Perairan yang ideal bagi pemeliharaan ikan adalah perairan yang mempunyai $\mathrm{pH}$ antara 6,5 - 8,5 (NTAC, 1968). Derajad keasaman $(\mathrm{pH})$ air waduk Sermo berkisar antara 7,0 - 8,9 (rata-rata 7,7 ) termasuk sesuai untuk kehidupan pakan alami dan ikan.

\section{Oksigen $\left(\mathrm{O}_{2}\right)$ terlarut dan karbon dioksida $\left(\mathrm{CO}_{2}\right)$}

Suatu perairan dapat mendukung kehidupan ikan dengan layak dan kegiatan perikanan berhasil, maka kandungan $\mathrm{O}_{2}$ terlarutnya tidak kurang dari $4 \mathrm{mg} / \mathrm{l}$ (NTAC, 1968). Menurut Swingle (1968) dan Pescod (1973) kandungan $\mathrm{O}_{2}$ terlarut minimal $2 \mathrm{mg} / \mathrm{l}$ sudah cukup mendukung kehidupan organisme perairan secara normal jika tidak ada senyawa lain yang bersifat racun. Oksigen terlarut air waduk Sermo berkisar antara 1,0012,20 ppm (rata-rata 5,69 ppm). Kandungan $\mathrm{O}_{2}$ terlarut air waduk Sermo semakin ke dalam mengalami penurunan kemudian relatif tetap (rata-rata mencapai 3,80 ppm). Perairan waduk Sermo mempunyai kandungan $\mathrm{O}_{2}$ terlarut yang cukup baik untuk mendukung kehidupan ikan dan jasad-jasad makanannya.

Karbon dioksida $\left(\mathrm{CO}_{2}\right)$ air merupakan bahan utama dalam fotosintesa, tetapi jika dalam konsentrasi yang tinggi dapat bersifat menghambat penyerapan $\mathrm{O}_{2}$ oleh darah di dalam tubuh ikan. 
Kandungan $\mathrm{CO}_{2}$ bebas sebaiknya tidak melampaui $25 \mathrm{ppm}$ dan kandungan $\mathrm{O}_{2}$ terlarut selalu tersedia dalam jumlah cukup. Dalam perairan dengan kandungan $\mathrm{O}_{2}$ terlarut $2 \mathrm{ppm}$, konsentrasi $\mathrm{CO}_{2}$ sebesar 12 ppm cukup aman bagi kehidupan ikan (NTAC, 1968). Pengaruh $\mathrm{CO}_{2}$ bebas terhadap ikan sangat merugikan jika konsentrasinya meningkat pada waktu kandungan $\mathrm{O}_{2}$ terlarut rendah (dibawah titik kritis) (Boyd, 1979). Karbon dioksida $\left(\mathrm{CO}_{2}\right)$ air waduk Sermo berkisar antara 0,00 - 1,40 ppm (rata-rata $0,52 \mathrm{ppm}$ ). Kandungan $\mathrm{CO}_{2}$ bebas di perairan Waduk Sermo semakin ke dalam mengalami kenaikan, kemudian relatif tetap (rata-rata mencapai $0,78 \mathrm{ppm}$ ). Perairan waduk Sermo mempunyai kandungan $\mathrm{CO}_{2}$ yang mendukung kehidupan fitoplankton dan tidak menghambat kehidupan ikan.

\section{Alkalinitas dan kesadahan air}

Alkalinitas suatu perairan menunjukkan kandungan basa yang bersenyawa dengan ion karbonat dan bikarbonat. Alkalinitas total air umumnya berasal dari ion karbonat dan bikarbonat. Swingle (1968) menyebutkan klasifikasi alkalinitas air untuk perikanan, yaitu : Alkalinitas antara 0-10 ppm termasuk sangat rendah (sangat asam), 10-50 ppm termasuk rendah, 50-200 ppm termasuk sedang dan > $200 \mathrm{ppm} \mathrm{CaCO}_{3}$ termasuk tinggi (sangat alkalin).

Kesadahan total air merupakan kandungan ion-ion alkali total (biasanya hanya meliputi $\mathrm{Ca}$ dan $\mathrm{Mg}$ ). Air sadah (keras) mengandung alkali tinggi, sedangkan air lunak mengandung alkali rendah (Boyd, 1989). Sawyer dan McCarty (1967) cit Boyd (1979) mengklasifikasikan kesadahan air yang meliputi air lunak berkisar antara 0-75 ppm, sedang 75150 ppm, keras 150-300 ppm dan sangat keras $>300 \mathrm{ppm} \mathrm{CaCO}_{3}$. Perairan yang mempunyai kesadahan lunak, lebih rendah dari $20 \mathrm{ppm}$ dianggap secara biologis kurang produktif (Boyd, 1979). Perairan waduk Sermo mempunyai alkalinitas sedang dan kesadahan lunak, cukup baik untuk mendukung kehidupan pakan alami (plankton) dan ikan. Produktivitas perairan yang lebih besar bukan akibat langsung dari konsentrasi alkalinitas yang lebih tinggi, tetapi dari tingkat fosfat atau hara-hara esensial lainnya yang tinggi sesuai dengan tingginya alkalinitas (Boyd, 1979). Alkalinitas dan kesadahan air dapat digunakan untuk menduga kesuburan suatu perairan (Swingle, 1968).

Alkalinitas dan kesadahan air waduk Sermo masing-masing berkisar antara 30-156 ppm $\mathrm{CaCO}_{3}$ (rata-rata $94 \mathrm{ppm}$ $\mathrm{CaCO}_{3}$ ) dan 36-118 ppm $\mathrm{CaCO}_{3}$ (ratarata $73 \mathrm{ppm} \mathrm{CaCO}_{3}$ ). Alkalinitas total air lebih besar daripada kesadahan total berarti bahwa ion-ion karbonat $\left(\mathrm{HCO}_{3}+\right.$ $\mathrm{CO}_{3}{ }^{2-}$ ) umumnya bersenyawa dengan $\mathrm{K}^{+}$ dan $\mathrm{Na}^{+}$daripada $\mathrm{Ca}^{2+}$ dan $\mathrm{Mg}^{2+}$. Jika kesadahan total lebih besar daripada alkalinitas total, beberapa $\mathrm{Ca}^{2+}$ dan $\mathrm{Mg}^{2+}$ lebih bersenyawa dengan $\mathrm{SO}_{4}{ }^{2}, \mathrm{Cl}^{-}$, $\mathrm{SiO}^{3=}$ atau $\mathrm{NO}^{3-}$ daripada dengan ion karbonat $\left(\mathrm{HCO}_{3}\right.$ dan $\left.\mathrm{CO}_{3}{ }^{2-}\right)$ (Boyd, 1979).

\section{Daya hantar listrik dan zat padat terlarut total}

Daya hantar listrik (DHL) merupakan kemampuan air untuk menghubungkan aliran listrik. Nilai DHL suatu perairan umumnya meningkat sesuai dengan peningkatan konsentrasi zat padat terlarut total (total dissolved solid/TDS)(Boyd, 1979). Batas toleransi ikan terhadap DHL dipengaruhi oleh kesadahan perairan tersebut. Dalam perairan lunak (soft water) untuk kehidupan yang baik, ikan dapat menerima DHL yang berkisar antara $\quad 150-500 \mu \mathrm{mhos} / \mathrm{cm}$. Pada nilai DHL di atas $500 \mu \mathrm{mhos} / \mathrm{cm}$ ikan mulai dalam keadaan stres, sedangkan di atas $1000 \mu \mathrm{mhos} / \mathrm{cm}$ ikan tidak tahan hidup (Sylvester cit Kartamihardja, 1987). Nilai DHL akuades sekitar $1 \mu \mathrm{mhos} / \mathrm{cm}$ sedangkan dalam perairan umumnya berkisar antara $20-1.500 \mu \mathrm{mhos} / \mathrm{cm}$ (Boyd, 1979). Nilai DHL dan TDS perairan waduk Sermo masing-masing berkisar antara 92-252 ( $\mu \mathrm{mhos} / \mathrm{cm})$ (rata-rata 158 $\mu \mathrm{mhos} / \mathrm{cm}$ ) dan113-320 gr/l (rata-rata 201 
g/l). Nilai DHL dan TDS perairan waduk Sermo sesuai untuk kehidupan pakan alami (plankton) dan ikan.

\section{Nitrogen (Amonia, amonium, nitrat, $N$ total)}

Nitrogen merupakan salah satu unsur hara utama untuk pertumbuhan dan perkembangan plankton dan tanaman air. Nitrogen berperan untuk pembentukan protein dalam tubuh jasad hidup. Bahan-bahan organik yang berasal dari sisa-sisa hewan atau tanaman di dalam air dapat mengalami perombakan dan mineralisasi, antara lain melepaskan $\mathrm{NH}_{3}$. Dalam perairan yang aerob dan dengan bantuan mikroorganisme, $\mathrm{NH}_{3}$ mengalami nitrifikasi menjadi $\mathrm{NO}_{2}$ dan $\mathrm{NO}_{3}$. Amonia yang terlarut di dalam air bersifat racun terhadap ikan. Pescod (1973) cit. Kartamihardja (1987) menyebutkan bahwa dalam perairan tropis kandungan $\mathrm{NH}_{3}$ yang layak untuk kehidupan ikan tidak lebih dari $1 \mathrm{ppm}$. Amonium $\mathrm{NH}_{4}$ dan $\mathrm{NO}_{3}$ tidak bersifat racun terhadap ikan, senyawa ini dapat diserap fitoplankton dan tanaman air untuk pertumbuhan dan perkembangannya.

Kadar $\mathrm{NH}_{3}, \mathrm{NH}_{4}^{+}, \mathrm{NO}_{3}{ }^{-}$dan $\mathrm{N}$ total dalam perairan waduk Sermo masingmasing berkisar antara 0,0025-0,2446 ppm (rata-rata 0,0391 ppm); 0,3401$1,3581 \mathrm{ppm}$ (rata-rata $0,5125 \mathrm{ppm}$ ); 0,2800-7,0624 ppm (rata-rata 1,5116 ppm) dan 0,30-11,50 ppm (1,54 ppm). Kandungan $\mathrm{O}_{2}$ terlarut cukup tersedia untuk proses oksidasi (nitrifikasi), sehingga transformasi $\mathrm{N}$ dalam perairan waduk Sermo kelihatannya ke arah pembentukan $\mathrm{NO}_{3}{ }^{-}$. Kadar $\mathrm{NH}_{3}$ air masih dibawah batas ambang untuk mengganggu kehidupan ikan. Kadar $\mathrm{NH}_{4}{ }^{+}$dan $\mathrm{NO}_{3}$ tersedia banyak untuk mendukung kehidupan fitoplankton.

\section{Fosfat}

Unsur hara $P$ merupakan salah satu unsur hara yang penting disamping $\mathrm{N}$, untuk metabolisme sel dalam plankton atau tanaman air. Hara $\mathrm{P}$ dalam bentuk ortofosfat $\left(\mathrm{PO}_{4}{ }^{3-}\right)$ sifatnya larut dalam air dan dapat dimanfaatkan oleh fitoplankton dan tanaman air. Unsur hara $P$ umumnya sebagai faktor pembatas atau penentu dalam tingkat kesuburan perairan, baru kemudian hara N. Pada umumnya kandungan fosfat dalam perairan umum tidak pernah lebih dari 0,1 ppm, kecuali jika ada penambahan dari air buangan atau daerah pertanian (Lund, 1971 cit. Krismono dkk., 1987). Di dalam air, fosfat dapat membentuk persenyawaan dengan ion-ion logam. Persenyawaan ini tergantung $\mathrm{pH}$ air. Pada $\mathrm{pH}$ asam, fosfat bersenyawa dengan ion $\mathrm{Al}^{3+}$ dan $\mathrm{Fe}^{3+}$, sedangkan pada $\mathrm{pH}$ alkalis fosfat bersenyawa dengan ion $\mathrm{Ca}^{2+}$. Pada perairan dengan $\mathrm{pH}$ agak netral (6 - 7), fosfat lebih tersedia untuk dimanfaatkan oleh fitoplankton dan tanaman air (Boyd, 1979). Kandungan fosfat di perairan waduk Sermo berkisar antara tidak terdeteksi - 1,0500 ppm (rata-rata 0,1232 ppm). Fosfat air umumnya dalam jumlah sedikit dan segera dimanfaatkan untuk pertumbuhan fitoplankton. Fosfat air waduk Sermo lebih besar dari 0,1 ppm, kemungkinan berasal dari daerah kiri kanan aliran sungai yang digunakan untuk kegiatan pertanian.

\section{Sulfat}

Sulfat berperanan dalam metabolisme protein untuk pertumbuhan plankton dan tanaman air, disamping $\mathrm{NH}_{4}{ }^{+}, \mathrm{NO}_{3}{ }^{-}$dan $\mathrm{PO}_{4}{ }^{3-}$ yang sudah disebutkan terdahulu. Perombakan bahan organik dan ekskresi organisme dalam keadaan aerob akan menghasilkan sulfat $\left(\mathrm{SO}_{4}{ }^{2}\right)$. Dalam perairan dengan salinitas lebih tinggi mengandung sulfat yang lebih besar daripada perairan dengan salinitas yang lebih rendah (Boyd, 1979). Secara umum bentuk sulfur pada bagian permukaan perairan adalah sulfat $\left(\mathrm{SO}_{4}{ }^{2}\right)$. Dalam keadaan perairan anaerob sulfat direduksi menjadi sulfida. Sulfida dalam bentuk hidrogen sulfida bersifat racun terhadap ikan pada konsentrasi 1,0 ppm (Klein, 1962 cit. Kartamihardja dkk., 1987). 
Kandungan sulfat $\left(\mathrm{SO}_{4}{ }^{-}\right)$air waduk Sermo berkisar antara 8,4-84,9 ppm (rata-rata 33,7 ppm), cukup tersedia baik untuk pertumbuhan plankton. Kandungan sulfat rata-rata sepanjang badan air waduk Sermo relatif tetap, yaitu sekitar 33 $\mathrm{ppm}$. Sulfat ini merupakan hasil perombakan dari bahan organik selama penggenangan waduk. Kandungan $\mathrm{O}_{2}$ terlarut air waduk Sermo akan mengubah menjadi $\mathrm{SO}_{4}=$ dan tidak memberi kesempatan diubah menjadi sulfida. Suhu air rata-rata sekitar $29{ }^{\circ} \mathrm{C}$ dan $\mathrm{pH}$ yang agak alkalis menunjukkan bahwa kesetimbangan tidak kearah pembentukan $\mathrm{H}_{2} \mathrm{~S}$. Kandungan $\mathrm{H}_{2} \mathrm{~S}$ akan menurun pada suhu dan $\mathrm{pH}$ perairan yang semakin tinggi.

\section{Bahan organik total}

Bahan organik waduk Sermo berasal dari sisa-sisa organisme (hewan atau tanaman) yang sudah ada sebelum penggenangan atau berasal dari aliran sungai yang memasuki waduk. Bahan organik total meliputi bahan organik terlarut maupun tersuspensi. Selama aliran air atau penggenangan waduk, bahan organik akan mengalami perombakan oleh mikroorganisme perombak. Laju perombakan ini sangat dipengaruhi oleh jenis bahan organik, ketersediaan $\mathrm{O}_{2}$ terlarut, derajad keasaman dan suhu air. Bahan organik yang sudah ada sebelum penggenangan biasanya masih 'mentah'. Bahan organik yang terangkut aliran air sungai biasanya sudah mengalami perombakan sepanjang aliran tersebut. Bahan organik ini umumnya mempunyai nisbah $\mathrm{C} / \mathrm{N}$ tinggi sehingga perom- bakannya lebih lambat dibandingkan bahan organik setempat yang berasal dari organisme plankton yang mati (dengan nisbah $\mathrm{C} / \mathrm{N}$ rendah). Perombakan bahan organik akan meningkat jika $\mathrm{O}_{2}$ terlarut selalu tersedia dalam jumlah yang lebih dari cukup, $\mathrm{pH}$ meningkat hingga 8,5 dan suhu meningkat hingga $35^{\circ} \mathrm{C}$ (Boyd, 1982). Bahan organik total diperairan waduk Sermo berkisar antara 5,7-22,1 ppm (rata-rata 12,8 ppm).

Secara vertikal kandungan bahan organik waduk Sermo tidak menunjukkan beda yang nyata. Kandungan bahan organik di permukaan perairan sedikit lebih besar daripada bagian tengah dan dasar, hal ini kemungkinan terutama karena bahan organik yang berasal dari organisme plankton permukaan. Suhu dan $\mathrm{pH}$ air waduk Sermo, seperti juga pada perairan waduk lainnya didaerah tropis umumnya sesuai untuk perombakan bahan organik. Perairan waduk Sermo juga mengandung $\mathrm{O}_{2}$ terlarut yang akan memperlancar kegiatan perombakan bahan organik tersebut.

\section{Plankton dan tanaman air}

Plankton merupakan organisme perairan baik sebagai produsen primer (fitoplankton) maupun sebagai produsen sekunder (zooplankton). Plankton berperan penting sebagai sumber makanan untuk kehidupan ikan pemakan plankton dan organisme sejenisnya. Kelimpahan plankton sangat berhubungan dengan tingkat produktivitas suatu perairan.

Tabel 2. Jumlah spesies, kerapatan dan keanekaragaman selama studi

\begin{tabular}{|l|r|r|r|r|r|r|}
\hline Parameter/Bulan (1996/97) & \multicolumn{1}{c|}{ Sept' } & \multicolumn{1}{c|}{ Okt' } & \multicolumn{1}{c|}{ Nop' } & \multicolumn{1}{c|}{ Des.' } & Jan' & Rata-rata \\
\hline Jumlah spesies & 12 & 15 & 10 & 10 & 12 & 12 \\
\hline Kerapatan (individu/l) & 38.885 & 34.456 & 17.771 & 22.877 & 9.272 & 24.644 \\
\hline Indeks Keanekaragaman & 0,756 & 0,836 & 0,659 & 0,659 & 0,886 & 0,759 \\
\hline
\end{tabular}


Plankton pada perairan mengalir umumnya kelimpahannya relatif kecil karena terbawa aliran air. Setelah penggenangan, plankton penghuni perairan waduk ditentukan oleh jenis plankton dari sungai yang masuk ke waduk tersebut.

Jumlah jenis, kerapatan dan indeks keanekaragaman plankton masingmasing stasiun (bulan September 1996 s/d Januari 1997) dapat dilihat dalam Tabel 2. Pada masing-masing stasiun jenis fitoplankton lebih banyak dijumpai daripada zooplankton. Jumlah fitoplankton berkisar dari sedikit hingga sedang. Jenis dan jumlah zooplankton sedikit. Selama penelitian, jenis fitoplankton yang sering teramati dalam jumlah yang cukup banyak adalah Nitzschia sp., Nostoc sp. dan Peridinium. Jenis fitoplankton yang sering dijumpai pada 3 bulan pertama (musim kemarau hingga awal musim hujan) adalah Anabaena, Closteriopsis longissima var tropicana, Synechosystis aqualitis dan Chlorococcum humicola. Jenis fitoplankton yang sering dijumpai pada 3 bulan terakhir (musim hujan) adalah Leuvenia natans, Lyngbya birgei dan Schizomeris leiblinii. Fitoplankton jenis Arthrospira sp. pernah melimpah pada bulan Oktober 1996, khususnya pada stasiun 1 dan 5 .

Zooplankton dipermukaan perairan waduk Sermo yang sering dijumpai mempunyai macam dan jumlah yang sedikit, yaitu meliputi Brachionus sp., Cyclops sp., Frontoniella complanata, Loxodes magnus, Arcella sp., Dioptomus sp., Polyarthra sp., Sida crystallina, Moina sp.

Jenis plankton yang dijumpai selama pengamatan berkisar antara 10-15 spesies (rata-rata 12 spesies). Kerapatan dan indeks keanekaragaman plankton pada perairan waduk Sermo selama pengamatan masing-masing berkisar antara 11.126-41.347 individu/l (rata-rata 24.644 individu/l) dan 0,659-1,003 (rata-rata 0,759). Pada masing-masing stasiun menunjukkan nilai rata-rata jumlah spesies, kerapatan dan indeks keanekaragaman plankton masing-masing berkisar antara 11-13 spesies, 21.12028.180 individu/l dan 0,710-1,804. Hasil pengamatan tersebut menyebutkan bahwa jumlah spesies, kerapatan dan indeks keanekaragaman antara masingmasing stasiun tidak menunjukkan perbedaan jauh.

Pada bulan Oktober 1996 (awal musim hujan), teramati jumlah spesies plankton paling banyak, yaitu mencapai 15. Kerapatan plankton rata-rata paling banyak pada bulan September 1996, kemudian relatif semakin menurun hingga bulan Januari 1997. Genangan air pada waktu bulan Oktober 1996 baru mencapai elevasi sekitar $107-108 \mathrm{~m} \mathrm{dpl}$ (di atas permukaan laut). Volume ini masih sedikit dan kandungan serta masukan hara dari aliran air sungai kemungkinan meningkat. Genangan air waduk Sermo semakin lama semakin bertambah sehingga volume air dan luas genangan meningkat, maka terjadi pengenceran air dan kerapatan plankton menurun. Selama penelitian (September 1996 hingga Januari 1997) pada masing-masing stasiun tidak dijumpai adanya tanaman air. Tanaman air yang berpotensi sebagai gulma air kemungkinan ada di sepanjang aliran sungai bagian hulu dan sekitarnya. Hal ini perlu untuk selalu dipantau dan diwaspadai.

\section{Kesimpulan}

1. Kualitas air waduk Sermo sesuai untuk pengembangan perikanan, khususnya pada beberapa parameter yaitu : kecerahan, kekeruhan, suhu, $\mathrm{pH}$, oksigen terlarut, karbondioksida bebas, alkalinitas, kesadahan, DHL dan TDS.

2. Tingkat kesuburan perairan waduk Sermo termasuk rendah - baik, sesuai untuk mendukung kehidupan pakan alami (plankton), khususnya dari beberapa parameter yaitu : amonium, nitrat, fosfat dan sulfat. 
3. Kualitas dan kesuburan air atau biologi waduk belum stabil, masih dalam tahap pertumbuhan.

4. Pada permukaan perairan waduk Sermo lebih didominasi fitoplankton daripada zooplankton. Jumlah jenis fitoplankton sebanyak 11 - 13 spesies yang didominasi oleh jenis Nitzschia sp., Nostoc sp. dan Peridinium. Jenis zooplankton yang sering dijumpai adalah Brachionus sp., Cyclops sp. Tanaman air di perairan waduk Sermo tidak/belum dijumpai.

\section{Daftar Pustaka}

APHA, 1985. Standard Methods for the Examination of Water and Wastewater. APHA, Washington. 16 th ed.

Boyd, C.E., 1979. Water Quality in Warm Water Fish Ponds. Carffmaster. Inc, Opelika, Alabama.

and F. Lichtkippler, 1979. Water Quality Management in Fish Culture. Alabama Agriculture Experimental Station, Res. And Dev. Series No. 22, Auburn University, $30 \mathrm{p}$.

1982. Water Quality
Management for Pond Fish
Culture. Elsevier Sci. Publ. Co,
Amsterdam. 319 p.

1989. Water Quality Management and Aeration in Shrimp Farming. Fisheries and Allied Aquacultures Departemental Series No. 2. Alabama Agricultural Experiment Station, Auburn University, Alabama. 70 p.
Dinas Perikanan, 1995. Laporan Tahunan Dinas Perikanan Prop. DIY Tahun 1994. Dinas Perik. DIY.

EPA, 1983. Methods for Chemocal Analysis of Water and Waste. EPA, Cincinnati, Ohio.

FWPCA, Washington DC. 234 p.

Kartamihardja, E.S., AS. Nastiti, Krismono, K. Purnomo, dan A. Hardjamulia, 1987. Penelitian Limno Biologis Waduk Saguling Pada Tahap Pra-Inundasi. Bull. Penel. Perik. Darat 6 (3) : 32-62.

Krismono, DWH. Tjahjo, A. Hardjamulia, S. Nuroniah dan C. Umar, 1987. Penelitian Limno Biologis Waduk Saguling Pada Tahap PostInundasi. Bull. Penel. Perik. Darat 6 (3) : 1-31.

NTAC, 1968. Water Quality Criteria.

Pescod, M.B., 1973. Investigation of Rational Effluent and Stream Standards for Tropical Countries. AIT, Bangkok. 59 p.

Swingle, H.S., 1968. Standardization of Chemical Analysis for Waters Ponds Muds. FAO Fish. Rep. 44 (4) : 397-406.

Triyatmo, B., Rustadi, Djomanto, S.B., Priyono, Krismono, N Sehenda, dan Kartamihardja, E.S., 1997. Studi Perikanan Di Waduk Sermo : Studi Biolimnologi. Lembaga Penelitian UGM bekerjasama dengan Agricultural Research Management Project BPPP. 65 hal 